\title{
TRABALHO, SOCIABILIDADE E INDIVIDUAÇÃO
}

\author{
WORK, SOCIABILITY AND INVIDUALIZATION
}

Sergio Lessa ${ }^{1}$

Resumo $\mathrm{O}$ ensaio argumenta que o fato de vivermos em uma sociedade que se reproduz enquanto uma 'imensa coleção de mercadorias' faz com que a mercadoria seja a relação social predominante entre os indivíduos. Como, entre as características decisivas da mercadoria, está o desprezo da utilidade dos produtos do trabalho na mesma propoprção do predomínio do lucro (o predomínio do valor de troca sobre o valor de uso), uma sociedade mercantil é aquela na qual a produção tem por objetivo não as necessidades humanas, mas o lucro. Com a crise estrutural do capital que se instaura a partir dos anos 70 (Mészáros), a manutenção de uma sociedade que se reproduz pela mediação da reprodução da mercadoria impõe aos seres humanos uma vida crescentemente alienada. Alienada em dois sentidos: as necessidades humanas comparecem de modo cada vez mais débil na produção social e, por outro lado, a produção perdulária e destrutiva torna-se a expressão predominante da desumanidade do capital. É neste conjunto de fatores que se baseiam as determinações fundamentais que articulam, hoje, o trabalho, a totalidade social (a sociabilidade) e a reprodução dos indivíduos (a individuação).

Palavras-chave ontologia; Marx; Lukács; Mészáros.
Abstract The essay argues that the fact of us living in a society that reproduces while a 'huge collection of merchandize' forces the merchandize to be predominant social relation between individuals. Since, among the decisive characteristics of the merchandize, we have the contempt for the usefulness of the products of labor (the supremacy of the Exchange value over the vale of use), a Merchant society is that in which the production has as its purpose not the human needs, but profit. With the structural crisis of capital which is installed from the 1970's, (Mészáros), the maintenance of a society which reproduces by the mediation of reproduction of merchandize imposes to the human beings a life increasingly alienated. Alienated in two senses: the human needs present themselves in a manner that is weaker and weaker in social production and, on the other hand, the spendthrift and destructive production becomes the predominant expression of the inhumanity of capital. It is in this group of factors that the fundamental determinations that articulate, today, labor, social wholeness (sociability) and reproduction of individuals (individuality) is based.

Key words ontology; Marx; Lukács; Mészáros. 


\section{Introdução}

A Irlanda sempre foi um lugar de vida dura, de muito trabalho e esforço para se tirar do solo pedregoso o imprescindível à sobrevivência. E, além disso, só raramente gozou de autonomia. É um católico, São Patrício, e não um herói celta, seu patrono. Talvez por causa disto, todo setembro, em Rathcroghan, eram realizadas festividades que se estendiam da segunda quinta-feira do mês até a terça-feira seguinte. O costume, nesses dias, era que ninguém poderia ir para a cama com fome. Os ricos eram obrigados a colocar algumas de suas reservas de alimento à disposição dos remediados, estes deveriam servir ao populacho, que então fartava-se como sabia que faria apenas no ano seguinte. Na terça-feira, ao pôr do sol, anunciava-se: 'A alegria terminou!' (The feast 2 is over!). Na quarta-feira, tudo retornava ao normal: os miseráveis voltavam a utilizar cinzas para condimento, pois não podiam pagar o preço do sal.

Esta frase, 'A alegria (a festa, a farra) terminou' levou-me a considerar que, ainda que miseráveis, os irlandeses sabiam que a alegria coletiva voltaria no ano seguinte. Nós, por outro lado, vivemos em uma civilização que teima em anunciar: 'as alegrias coletivas terminaram e não têm data para retornar'.

Nem me passa pela cabeça que os irlandeses da época de São Patrício seriam mais felizes que nós - não é isto, em absoluto. A verdadeira questão não está em uma relação comparativa com o passado, mas no nosso presente. As alegrias coletivas estão, de fato, vetadas, e não há data para o fim do embargo.

Não há um consenso na avaliação do momento que vivemos. As teses são muitas e são díspares, por vezes antagônicas. Ainda assim, é facilmente constatável que as previsões que poderíamos chamar de otimistas, feitas há algumas décadas, estão, todas elas, sendo negadas pelo andar da carruagem. Há cerca de quarenta anos, Alvin Toffler e Daniel Bell anunciaram que estaríamos em transição para uma sociedade pós-industrial (o que para eles significaria uma sociedade radicalmente diferente da nossa). Não apenas a miséria seria coisa superada, mas as vidas das pessoas seriam radicalmente alteradas pelas novas tecnologias e riquezas. Eles próprios apenas davam sequência a uma série de previsões igualmente otimistas realizadas na década de 1960, como as de Sergio Mallet, que anunciou, em 1963, que os operários seriam substituídos pelas máquinas automáticas e que uma sociedade sem trabalho manual, e portanto, segundo ele, sem exploração e sem classes, estava no horizonte próximo. Em 1984, Piore e Sabel publicaram o influente Second industrial divide: opportunity for prosperities, no qual previam que a entrada do modelo japonês (o toyotismo, como ficou conhecido) nas economias ocidentais poderia levar a uma sociedade de 
pequenos produtores, portanto mais democrática, porque sem grandes disparidades de poder econômico.

Não demorou muitos anos e um novo trio de previsões otimistas veio a público. Apesar de terem se tornado mais conhecidas somente depois das de Lojkine e Schaff, as teses de Negri e Lazzarato (depois com o acréscimo de Hardt) acerca do trabalho imaterial são mais antigas. Segundo eles, desde o século XVI a história teria sido moldada por um misterioso "amor pelo tempo por se constituir". Na verdade, este "amor" não é tão misterioso assim, e tem suas origens em Espinosa, o famoso filósofo do século XVII. Mas, para o pensador holandês, esta categoria tinha um significado muito distinto do que lhe conferem Negri, Hardt e Lazzarato - e assim torna-se obscura. Por poderes nunca explicados, este amor pelo tempo por se constituir teria arrebentado os limites da sociedade feudal levando multidões às ruas para realizarem a Revolução Francesa e, por fim, teria provocado um paradoxo historicamente inédito: em 1917, teria levado multidões às praças na Rússia para, pela hipertrofia absoluta do Estado, finalmente conquistar a liberdade.

O resultado desse movimento, que se iniciou no século XVII e estaria se concluindo em nossos dias, segundo os autores, foi o surgimento do trabalho imaterial. Isto é, com o desenvolvimento das forças produtivas sob o capitalismo, a pressão dos trabalhadores foi se intensificando, na medida em que a riqueza também aumentava. A partir de algum ponto da segunda metade do século XX - os autores não são precisos -, a pressão operária rompeu com a lei do valor. Para resumir uma história cheia de meandros, os trabalhadores hoje conseguiriam arrancar um salário maior do que o valor da força de trabalho que vendem aos seus patrões e, assim, estaria rompido o capitalismo e aberta a transição ao comunismo. Nesta transição, que estaríamos vivendo em nossos dias, estariam superados os limites da produção capitalista e todo o corpo social seria igualmente produtivo. Consumo e produção seriam agora idênticos, consumir e produzir seriam a mesma coisa. Do mesmo modo, não haveria mais distinção entre pensar e fazer, entre prévia-ideação (teleologia) e objetivação, nos termos clássicos de Marx e Lukács, pois pensar já seria fazer e, claro, fazer já seria pensar. Isto é o trabalho imaterial ${ }^{3}$.

Para Lazzarato, Negri e Hardt, o comunismo estaria surgindo, hoje, dos "interstícios do capital", e a miséria, o desemprego, a violência teriam uma única causa: o velho que resiste ao novo. $\mathrm{O}$ "velho" seriam as forças da sociedade que resistem ao "comunismo", o empresariado que não reconhece para onde sopra o vento do futuro, bem como o movimento social e a esquerda que persistem na defesa dos direitos trabalhistas, das organizações sindicais etc. são integrantes do "velho capitalismo". Do mesmo modo, também faria parte do velho a luta contra o imperialismo, pois, se não mais haveria capital 
nacional, como se poderia falar em imperialismo? E por aí continuam eles. Se no discurso parecem muito radicais, na prática política os partidários do trabalho imaterial têm se revelado belos conservadores.

Um pouco antes de 'explodir no mercado de idéias' o conceito de trabalho imaterial, Lojkine e Schaff como que lhe prepararam o caminho.

Jean Lojkine, em A revolução informacional (1995), também anuncia o fim do capitalismo, das classes sociais e das mercadorias. Sua tese é simples. Como, segundo ele, viveríamos em uma sociedade de informação e não mais de produção, e ainda, como a informação não poderia ser mercadoria porque não é "matéria", então estaríamos transitando para uma sociedade pós-mercantil, porque as mercadorias estariam desaparecendo. $\mathrm{O}$ equívoco de Lojkine é duplo. Primeiro, a informação pode sim ser uma mercadoria. Uma aula ou um serviço, que não é matéria natural transformada pela mão humana, pode ser vendido e comprado do mesmo modo que um martelo. A mercadoria pode ou não ter peso, massa etc., pode ser um espetáculo teatral, uma apresentação de canto lírico ou uma tonelada de ferro. Em segundo lugar, os homens se organizam em sociedade para, primordialmente, produzirem o que necessitam. Cada modo de produção desenvolve as técnicas e as relações de produção que lhe são apropriadas. As novas tecnologias geradas no capitalismo estariam, se acreditássemos em Lojkine, operando um milagre. Conduzindo-nos, por sua própria ação, para além da produção e do capitalismo.

Esta é, também, a posição de Adam Schaff. A sociedade informática (1990) eliminaria o trabalho manual e, com ele, o proletariado. Não haveria mais emprego e o grande problema da humanidade seria o que fazer com o ócio. O grande impasse não mais estaria na produção, mas no que fazer com o tempo livre; as pessoas teriam que descobrir como preencher as suas vidas. A aposta de Schaff é que criariam novos hobbies.

A burguesia e o Estado não desapareceriam. Mas mudariam radicalmente suas formas de atuação: deslocariam grandes somas de riquezas para retirar da miséria os países mais pobres e não permitiriam que os desempregados caíssem na miséria. A riqueza acabaria com a miséria pela ação do Estado e da burguesia. Schaff faz, ainda, uma aposta, retomando a tese já adiantada em 1963 por Mallet. Em 15 anos (ele escreveu em 1985) não mais haveria qualquer trabalhador nas fábricas. Ele chega mesmo a anunciar que, no Japão, haveria, já naqueles anos (meados da década de 1980), fábricas sem trabalhadores, o que jamais foi confirmado por qualquer outro observador. Os 15 anos se passaram e todas as suas previsões foram fragorosamente negadas pela história.

Novas e otimistas teorias continuam a ser produzidas no ritmo das coleções de moda, pois, como diz Lipovetsky (1997), trocamos de idéias tal como trocamos de roupas, amores e carros. E todas estão sendo negadas pela his- 
tória. A experiência cotidiana nos possibilita perceber como o presente está pior que o passado e nos indica que o futuro promete ser ainda pior que o presente.

Mas por quê? Por que a vida está piorando e por que, apesar disso, as previsões otimistas teimam em continuar aparecendo?

\section{O 'falso socialmente necessário'}

As pessoas, aqui no sentido de humanidade, são o que elas fazem. Os seres humanos são as relações sociais que estabelecem entre si; os indivíduos são as conexões que estabelecem com a história da qual são partícipes. Como vivemos em uma sociedade que produz mercadorias, fazemos a nós próprios "guardiões de mercadorias". Os da classe dominante são "guardiões do capital", os assalariados são guardiões da sua força de trabalho, a única mercadoria que têm para vender. Todavia, como a riqueza do patrão é produzida pelo trabalhador, o capital da burguesia nada mais é que a riqueza produzida pelo operário e, assim, o capital termina revelando-se o que de fato é: a força de trabalho convertida em propriedade do burguês. No fundo, portanto, o burguês e o proletário são guardiões da mesma mercadoria sob formas diversas. Isto que vale para o burguês e o operário vale para todos os trabalhadores, entre eles os assalariados em geral. E vale também para os marginalizados e desempregados: são guardiões que são miseráveis por não conseguirem vender suas mercadorias.

As mercadorias têm uma propriedade curiosa. Tal como Midas, que transformava em ouro tudo o que tocava, as mercadorias, ao serem produzidas, convertem os homens em sua imagem e semelhança. As mercadorias não "podem ir ao mercado" por si próprias, não podem se trocar umas pelas outras a não ser que os seres humanos as troquem. Portanto, para que as mercadorias "se refiram umas às outras como mercadorias, é necessário que os seus 'guardiões' se relacionem entre si como pessoas cuja vontade reside" nas mercadorias, de tal modo que troquem suas mercadorias segundo as vontades do vendedor e do comprador. Mas, para que as pessoas se relacionem enquanto vendedores e compradores, é preciso, ainda, que se reconheçam "reciprocamente como proprietários privados. Esta relação jurídica, cuja forma é o contrato, desenvolvida legalmente ou não, é uma relação de vontade, em que se reflete a relação econômica" (Marx, 1983, p. 79).

Quando a economia força o indivíduo a vender e comprar mercadorias para viver, as relações de concorrência moldam até mesmo a 'vontade' dos indivíduos: é assim que vivemos em função do dinheiro, que é a mercadoria das mercadorias, a mercadoria universal. 
É lugar comum que vivemos em uma sociedade na qual o dinheiro é tudo. Todavia, sob esta realidade se esconde algo curioso: fomos nós, os humanos, que criamos o dinheiro. Aquilo que hoje é 'tudo', diante do qual nossas necessidades só fazem sentido se forem lucrativas, não é, como a força da gravidade, algo dado pela natureza. Todavia, nossos destinos são determinados muito mais pelo dinheiro que criamos do que pela gravidade que não controlamos. O poder do dinheiro sobre nós vem de nós próprios e, todavia, parece que ele tem uma força tão descomunal que não poderia ser de modo algum humana.

É este feitiço, que faz com que a criatura comande o criador, o que Marx denominou de "fetichismo da mercadoria". Ao produzir uma sociedade que nada mais é que uma coleção de mercadorias, fizemos da humanidade pessoas que vivem como guardiões das mercadorias, pessoas cuja vontade reside em levar as mercadorias ao mercado, cuja vontade reside na necessidade de as mercadorias trocarem-se reciprocamente.

É assim que tudo o que fazemos gira em torno do lucro, da propriedade privada. Desenvolvemos robôs que poderiam retirar do trabalho manual milhões de pessoas e poderiam reduzir o tempo de trabalho de todos nós. Mas, como o objetivo da tecnologia é o lucro e não a necessidade dos homens, nos comportamos como guardiões das mercadorias: usamos os robôs para fazer os operários produzirem mais em um ritmo de trabalho ainda mais estafante e jogamos no desemprego os trabalhadores agora excedentes. Produzimos hoje três vezes mais alimentos do que o necessário para dar 180 gramas de proteínas e 3.600 calorias diárias para todos os habitantes da Terra, independentemente de idade ou profissão. Todavia, se toda esta comida for colocada no mercado, a oferta aumentará, o preço cairá e adeus lucro. Então os governos estabelecem estoques reguladores (de preços, não da fome) e tiram do mercado, jogam fora, deixam estragar etc., toda a comida que for necessária para que o preço não caia. O Estado gasta recursos para tirar comida de circulação, o que significa investir dinheiro para manter a fome em um mundo no qual há comida para todos - porque somos guardiões das mercadorias e nossas vontades são as vontades das mercadorias.

Hoje há em São Paulo 47 mil famílias de sem-teto e mais de $80 \mathrm{mil}$ domicílios excedentes, que não conseguem ser vendidos ou alugados. O problema da moradia em São Paulo está, portanto, resolvido. Mas, como a questão é o lucro e não a moradia para as pessoas, devemos continuar construindo apartamentos e casas que não são mais necessárias. E devemos fazer as pessoas comprá-los, mesmo que não necessitem. A especulação imobiliária se encarregará deste milagre. Desvaloriza áreas inteiras da cidade para forçar as pessoas, guardiões das mercadorias, a comprar residências em novos bairros. Ou, o inverso, valoriza áreas para atrair com- 
pradores que já possuem imóveis. E quando apenas este movimento especulativo não for mais suficiente, o Estado dará uma mão: programas de construção de casas populares ou financiamentos de imóveis para as 'classes A e B' (principalmente em períodos eleitorais).

Os exemplos são infinitos: da moda à guerra fazemos o que for lucrativo, não o que é humanamente necessário. Pense-se na barbaridade que é a construção de um arsenal nuclear suficiente para destruir o mundo 99 vezes. Do ponto de vista militar, uma vez só seria mais do que suficiente. E isto foi feito porque, para nós, guardiões das mercadorias, é mais 'sensato' construir as bombas do que sensatamente atender às necessidades humanas. Que coisa seria mais 'razoável' que preparar nossa autodestruição do planeta Terra - se isto for lucrativo?

Pode não parecer, mas isso se relaciona com o anúncio de que a 'Alegria terminou e não tem data para retornar', como veremos logo a seguir.

O capitalismo, por ser capitalismo, reproduz uma sociedade que concentra miséria em uma classe e riquezas em outra. Mas nem sempre o faz da mesma forma. Na história recente, houve um período que gerou a ilusão de que o capitalismo seria capaz de distribuir rendas e superar as misérias, alguns acharam até mesmo que o capitalismo estaria deixando de ser capitalismo. Esta fase ficou conhecida como o 'Estado de Bem-Estar' e coincidiu com um período de expansão econômica que perdurou por cerca de trinta anos, os 'trinta anos dourados' entre o fim da Segunda Guerra Mundial e a crise da década de 1970. A principal característica destes anos foi a acumulação do capital pela mediação de um mercado de consumo de massas, num processo que chamaram de 'círculo virtuoso': com maior consumo, poderse-ia aumentar a produção; com maior produção, os preços cairiam e aumentaria o consumo. Maior consumo geraria maior produção e menor preço; caindo os preços teríamos maior consumo e o círculo, em tese, se realimentaria até o infinito e levaria todos à prosperidade (claro que com alguns mais ricos que outros). A chave era manter o aumento do consumo. Para isso foi preciso aumentar os salários e diminuir as jornadas de trabalho, aumentar as férias e os direitos trabalhistas.

Para que todas essas medidas fossem adotadas por todas as empresas de um dado ramo econômico, sem que se alterasse a posição relativa de cada uma no mercado, o mecanismo mais adequado foi a construção de grandes sindicatos. Estes deveriam ficar nas mãos de uma burocracia sindical que aceitasse o papel que lhes destinava o sistema do capital: negociar com os patrões acordos coletivos que possibilitassem o aumento do consumo, mas, jamais, organizar os trabalhadores para lutarem contra o capital. E, como naqueles anos os salários estavam aumentando e os direitos trabalhistas se ampliando, não foi difícil convencer os trabalhadores de que o modelo americano seria melhor do que o modelo soviético, já convertido em stalinismo. Foi nesse momento 
histórico também que, tanto nos Estados Unidos como na Europa, uma onda política conservadora se fez presente. O macarthismo nos EUA e o gaullismo na França foram as melhores expressões do aumento da repressão sobre tudo o que não era pró-capitalista e também auxiliaram a manter os novos sindicatos dentro dos limites que interessavam ao sistema do capital.

A ampliação da massa salarial e as outras medidas de aumento do consumo nos países capitalistas centrais deram certo por alguns anos. Todavia, a contradição inerente ao capitalismo pela qual a produção aumenta mais rapidamente que o consumo voltou a se manifestar já no final da década de 1950. Para manter o sistema girando era preciso uma força de trabalho mais barata, a fim de que os preços diminuíssem ainda mais. Contudo, cortar os salários dos trabalhadores dos países capitalistas avançados significaria cortar o próprio mercado, justamente o oposto do pretendido. A saída foram as multinacionais. Transferem-se plantas industriais para o Terceiro Mundo para tirar vantagem de seus numerosos e baratos trabalhadores. E para que esses trabalhadores não se organizem, para que a transferência para os países menos desenvolvidos ocorra na situação a mais vantajosa para as multinacionais (financiamentos, renúncia fiscal, infra-estrutura etc.) e para que tais países não resistam à destruição de suas próprias indústrias pelas poderosas multinacionais, entram em cena os governos ditatoriais, que remodelam seus países para os 'novos tempos'. A política externa do Estado de Bem-Estar encarregou-se de plantar ditaduras por todo o Terceiro Mundo. E, somada às intervenções militares em todo o planeta (Vietnã, Oriente Médio, Coréia, Argélia, Irã, etc.), teve um efeito não pouco importante: a tortura renasce como instrumento judicial. Mesmo países como Inglaterra, França, Alemanha e Estados Unidos passam a empregá-la sistematicamente e, por vezes, até mesmo contra seus cidadãos e em seus próprios países (Millet, 1994). Lembremos do que ocorreu com os militantes do grupo Baader-Meinhof na Alemanha ou com os membros do IRA na Inglaterra. Como obra do Estado de Bem-Estar, chegamos ao final da década de 1960 com nove países 'democráticos' que ganhavam muito explorando o restante do planeta pleno de 'ditadores' - e com os trabalhadores de todo o mundo sem organizações autônomas para resistir ao avanço do capital. Nos países centrais, os operários foram 'ganhos' para o capital; no Terceiro Mundo, suas organizações foram destruídas pelas ditaduras e intervenções imperialistas.

\section{Tenha um pouco mais de paciência}

Pode parecer que não, mas, repetimos: isto tem relação com o anúncio do fim da alegria coletiva. Tenha um pouco mais de paciência, caro leitor, que logo trataremos da relação da sociedade com o trabalho e com a individuação. 
É nesse mundo dividido em ricos e pobres em uma escala historicamente inédita que entra em crise o Estado de Bem-Estar. O 'gargalo' que levou à crise é o mesmo desde o século XIX: a produção aumenta mais rapidamente que o consumo e conduz à superprodução. Como não é mais possível ampliar os mercados no ritmo necessário (nos países centrais os mercados estavam saturados e o Terceiro Mundo tinha se empobrecido ainda mais com a exploração feita pelas multinacionais), as empresas apenas poderiam crescer se tomassem o mercado de suas concorrentes. E, para isso, é preciso produzir melhor e mais barato. Melhor significa produtos tecnologicamente mais avançados e - num paradoxo apenas aparente - que quebrem mais cedo para que tenhamos de comprá-los novamente. Mais barato significa pagar menos salários. Para ambos os objetivos é preciso uma 'reestruturação produtiva', isto é, a adoção de novas tecnologias e técnicas de gerenciamento que possibilitem produzir mais com menos trabalhadores. E, de preferência, trabalhadores ainda menos especializados, para receberem salários mais baixos. Com o aumento do desemprego resultante da reestruturação produtiva, obtém-se ainda um 'positivo' efeito colateral: os trabalhadores são divididos entre uma 'aristocracia' que mantém seu emprego e a massa de desempregados. E tanto um como outro dispostos a fazer de tudo para manter o seu emprego ou para voltar a ter a carteira assinada (Gounet, 1999).

Foi assim que, contra o 'círculo virtuoso' dos anos dourados, impôs-se um 'círculo vicioso' no qual se aumenta a produção ao preço de aumentar também o desemprego. As fusões entre as empresas absorvem a maior parte dos investimentos, o que significa que não são criados novos postos de trabalho para substituir os que desapareceram (e isto não apenas no Terceiro Mundo, mas também nos países centrais). Aumento do desemprego significa menos consumo, e as empresas devem buscar aquela fatia do mercado cada vez mais restrita e composta pelos endinheirados que lucram com a crise. A produção de artigos perdulários e de luxo se amplia. Todo o sistema do capital passa a 'girar' mais rápido e mais instavelmente, e seus pressupostos são cada vez mais débeis e desequilibrados. É nesse contexto que guerras como as do Afeganistão e do Iraque (I e II, Bush pai e filho) convertem-se em válvulas de escape imprescindíveis ao sistema do capital 4 .

Isto é o que significa estarmos em uma crise estrutural do capital (Mészáros, 2002): a constante produção e venda de mercadoria, que é seu pressuposto fundamental, realiza-se em circunstâncias históricas cada vez mais adversas.

A conseqüência mais contundente desta crise é o desemprego. A geração que hoje tem ao redor de 50 anos praticamente não conheceu o desemprego. A geração que hoje chega aos 25 anos tem no desemprego uma perspectiva real na qual a vida irá se desdobrar. A relação entre as gerações se altera. Enquanto unidade econômica, a família tradicional entra em crise e o rendimento dos 'velhos' passa a ser cada vez mais importante para a 
manutenção dos 'novos'. Mas é com os operários e os trabalhadores mais pobres que a situação torna-se desesperadora. Sem emprego, a miséria material expressa-se nas páginas policiais e nas crianças nos sinais de trânsito. Caso se viva em grandes centros urbanos, devemos acrescentar também os seqüestros e as balas perdidas.

Em uma sociedade que é uma 'coleção de mercadorias', aquelas mercadorias não vendidas adentram ao processo de reprodução da sociedade como 'prejuízo', como uma mercadoria 'inútil' para a riqueza de seu guardião. O macarrão que fica na prateleira do supermercado, assim como a roupa ou o cimento não vendidos, são todos mercadorias inúteis, que dão prejuízo. Nada será gasto na sua manutenção e elas deverão ser descartadas o mais rapidamente possível. O supermercado não comprará mais deste macarrão etc. O mesmo é feito com a força de trabalho. Se ela é inútil (isto é, se não há emprego), ela deve ser descartada com o menor custo para o capital. Isto é, não se investe na sua manutenção, que, diferente do macarrão e do cimento, requer casa, comida, transporte, lazer, saúde, saneamento básico etc. Em outras palavras, a mercadoria força de trabalho, diferente das outras, é atributo de um ser humano. Contudo, em uma sociedade que é uma coleção de mercadorias, a pessoa cujos atributos não encontram compradores, tal como o cimento não vendido, será descartada. A sociedade capitalista é capitalista porque substitui, como motor de sua reprodução, o humano pelo capital. Tudo que adentra à reprodução do capital é mercadoria; e o que é humano mas não consegue ser mercadoria não tem lugar na reprodução da sociedade. Do mesmo modo como se economizam os recursos na manutenção do macarrão que não foi vendido, não serão gastos recursos na mercadoria força de trabalho que não for lucrativa.

A desumanidade do capitalismo não está apenas na desigualdade social. Isto é a ponta visível do iceberg. A desumanidade está em ser uma sociedade na qual o humano não tem lugar - a não ser quando pode ser transmutado em mercadoria. Ser uma coleção de mercadorias é precisamente isso: as relações sociais são, primordialmente, relações entre mercadorias; as pessoas encontram-se apenas indiretamente, pela mediação da mercadoria. E portanto, tudo aquilo que é humano e não pode ser convertido em fonte de lucro, está excluído da sociedade. O capitalismo é o lar das mercadorias, não das pessoas humanas. Para retomar uma idéia anterior: os humanos criaram uma criatura que não apenas os domina, mas também os oprime; não apenas os oprime mas, pior ainda, os destrói.

O que hoje marca os processos de individuação (este é o termo técnico, filosófico, para o processo de desenvolvimento da personalidade de cada indivíduo) é esta destruição do humano. E nesta destruição do que somos hoje enquanto pessoas humanas, novamente, a mercadoria é o seu núcleo decisivo. 


\section{Individuação e mercadoria}

O valor de cada mercadoria é estabelecido cotidianamente na concorrência com todas as outras mercadorias. É nessa relação do que uma mercadoria é 'contra todas as outras' que seu valor é estabelecido. Enquanto guardiões de mercadorias, as pessoas têm o valor de suas mercadorias. Ou seja, o valor de cada pessoa se estabelece na concorrência 'contra todos' os outros indivíduos. E nesta relação de concorrência, para cada indivíduo a sua riqueza pessoal é a coisa mais importante do mundo. Idiota - para a nossa sociedade - é aquele que não faça de tudo para enriquecer, mesmo que sua riqueza venha da destruição da humanidade. O que significa a produção de bombas atômicas senão exatamente isso? Nós somos hoje o que a mercadoria que produzimos faz de nós: pessoas individualistas que nos afirmamos socialmente contra todas as outras pessoas. A humanidade não é o local da nossa liberdade, mas a arena na qual cada um se embate contra todos. Somos indivíduos, personalidades, cuja relação com a humanidade (o gênero humano) é marcada pela concorrência e não pela cooperação.

Claro que o individualismo (o indivíduo que se constrói socialmente contra todos os outros indivíduos) tem imediatas repercussões éticas e morais. Mas é importante que percebamos que sua origem não é nem ética nem moral, mas sim o fato de produzirmos mercadorias. Produzimos mercadorias e nos fazemos, por esta produção, seus guardiões. É a sociedade capitalista, esta enorme 'coleção de mercadorias', que faz com que os valores individualistas predominem na ação das pessoas na vida cotidiana. E não o inverso. Por isso, enquanto não abolirmos a produção de mercadorias este individualismo também não será superado. Não há pregação moral ou ética que resolva o problema: somos individualistas porque somos guardiões de mercadorias e, enquanto não colocarmos no centro da produção as necessidades humanas, também nas ações dos indivíduos o humano não poderá predominar, sequer enquanto valores morais. É por isso que, hoje, pregações morais como a "Campanha contra a fome" liderada pelo Betinho ou campanhas de caridade são adequadas ao capitalismo: dão a sensação de estarmos fazendo algo (o que é reconfortante) e, ao mesmo tempo, sequer tocam as causas da situação. E, não raramente, têm ainda uma outra virtude do ponto de vista da sociedade em que vivemos, qual seja, freqüentemente acabam gerando lucros, como ocorre com não poucas ONGs.

Indivíduos que concorrem contra todos os outros e que têm a sociedade reduzida a espaço de disputas - indivíduos burgueses como somos todos nós - têm uma outra característica importante. São essencialmente solitários. São 'lobos da estepe'. 'Essencialmente' significa que só deixarão de ser solitários se deixarem de ser guardiões de mercadorias, isto é, se mudarem o fundamento do seu modo de ser. E 'solitários' não no sentido de serem 
eremitas, mas no sentido de apenas viverem uma vida coletiva quando concorrem e disputam entre si. Nosso 'valor' enquanto indivíduos se estabelece na concorrência incessante contra todos os outros indivíduos e, nesta concorrência, o presente é a única dimensão que importa. Pois, independentemente do nosso passado e do que faremos no futuro, o valor dos guardiões de mercadorias é estabelecido na relação imediata, vis-à-vis os outros guardiões de mercadorias. Por isso nossa vida cotidiana é um permanente contato com outras pessoas (trabalhamos em grandes empresas, habitamos cidades de milhões, compramos em shoppings e nos divertimos em multiplex ou em grandes templos, em estádios de futebol ou teatros etc.), já que sem esse contato não há concorrência possível. Pois, tal como as mercadorias que têm que ir ao mercado para se realizarem enquanto mercadorias, nós também temos que 'ir à luta' para podermos existir enquanto guardiões de mercadorias. Somos competitivos, tal como a mercadoria é concorrencial. Nosso valor não é o que somos e o que fazemos, mas o que somos e fazemos na concorrência com o que os outros são e fazem.

Até na relação com nós mesmos somos concorrenciais e competitivos. O indivíduo se sente melhor ou pior em um movimento que nunca está desconexo da sua conta bancária. O mesmo acontece com o casamento. Independentemente do que fizemos ou façamos na vida, é nossa situação econômica presente um elemento importantíssimo na auto-estima de qualquer um. Nós não nos encontramos com o outro enquanto pessoa humana, mas sempre o fazemos pela mediação da mercadoria. Pela mesma razão, nossa relação com nós mesmos tem a ver com nosso valor enquanto guardiões de mercadorias. Sem contatos humanos a não ser pela mediação da mercadoria, sem vivência coletiva senão a da concorrência, como poderemos deixar de ser essencialmente solitários?

Numa sociedade concorrencial, na qual os indivíduos estão sempre sozinhos e a única vivência coletiva possível é a luta de cada um contra todos, à solidão se acresce a insegurança; à ameaça permanente e presente soma-se a angústia e, como agora virou moda, o estresse. A reação individual típica a esta situação tem sido a tentativa de construir um mundinho particular, isolado, escondido e protegido do mundo exterior, com o qual tentamos contrabalançar as fontes de angústia que vêm do mundo exterior. Lá fora, somos guardiões de mercadorias, aqui dentro tentamos ser pessoas humanas nas quais são preservados os valores morais, os sentimentos, as emoções, as carências autenticamente humanas. Tipicamente, somos indivíduos divididos entre o cidadão e o burguês. Agimos como se nossas ações de guardiões de mercadorias fossem o que somos e nos isolamos no espaço privado como se não fôssemos guardiões de mercadorias, mas sim pessoas humanas. Como, todavia, não somos duas personalidades, mas apenas uma, temos que converter esta dualidade em alguma forma de unidade que nos possibilite 
sobreviver enquanto indivíduos. A única alternativa para colocar estas duas porções tão distintas, díspares, em um todo mais ou menos homogêneo é a superficialidade das emoções e da razão. Como somos uma única e mesma pessoa, e já que nossos atos enquanto guardiões de mercadorias determinam nossa sobrevivência no mercado, também apenas enquanto guardiões de mercadorias podemos nos isolar para construir nosso mundinho particular. Este isolamento nunca pode dar certo. Apenas podemos ser cidadãos se sobrevivermos enquanto burgueses, assim nosso mundinho particular não pode deixar de ser a extensão do burguês que agora se recolhe.

Esta cisão das nossas individualidades, todavia, tem uma outra conseqüência. Como a angústia (gerada pela situação de se viver solitariamente as ameaças oriundas da concorrência contra tudo e contra todos) não pode se expressar nas ações dos guardiões de mercadorias sob pena de fazermos maus negócios (nos vendermos abaixo do nosso valor), a angústia só pode se expressar plenamente na nossa vida afetiva e individual. E como não podemos mudar a nossa sociedade por um ato de vontade própria, buscamos o paliativo de colocar sob controle os afetos que geram angústias. Dito com outras palavras, temos que buscar uma conexão afetiva e intelectual cada vez mais superficial com o que somos enquanto guardiões de mercadorias, para que possamos diminuir um pouco a sensação de angústia que no âmbito privado somos forçados a sentir. O que significa que buscamos uma conexão com a vida cada vez mais pobre, pontual e efêmera. Fazemos o que somos obrigados e somos o que não gostamos. Por isso, queremos deixar para trás o mais rapidamente esta porção das nossas vidas para que não seja também destruído o remanescente de humanidade que conseguimos preservar em nosso mundinho privado. Desejamos nos esquecer do mundo tão logo possamos. Divertir-se tornou-se sinônimo de tudo o que nos 'liberta' desse mundo e que nos faça esquecer o que somos e o que fazemos. Melhor a televisão que nos impede de entender e refletir o mundo em que vivemos, melhores os filmes que nos fazem descolar afetiva e intelectualmente do que fazemos imediatamente antes e depois do cinema. E claro, nada de se conhecer a história, a arte, a literatura etc., pois tudo isso nos faz ainda mais angustiados. Não lemos jornais, eles só nos trazem 'notícias ruins'. É assim que, apesar do enorme conhecimento gerado nas últimas décadas, das possibilidades de acesso à informação, compomos coletivamente um processo de reprodução ampliada da ignorância. Somos personalidades cada vez mais fragmentadas, superficiais afetiva e racionalmente - cada vez mais ignorantes. E esta, novamente, é uma situação histórica, uma situação genérica que não pode ser radicalmente alterada na esfera da vida individual. Não há saída individual para este problema, repetimos, porque somos o que fazemos e, se produzimos mercadorias, necessariamente seremos seus guardiões. 
Ao adentrarmos a crise estrutural do capital, esta situação se degradou e a intensidade das desumanidades ganhou um novo patamar. Há mais seres humanos do que a quantidade de força de trabalho que o sistema do capital necessita: a concorrência se transforma em luta aberta pela sobrevivência e a vida cotidiana vai incorporando elementos de uma guerra civil (Enzensberger, 1995).

Ao invés de a crise nos levar a tomar consciência desta situação histórica, ocorre - nos processos de individuação - o oposto. Ao menos no curto prazo. Ao contrário de revolta, gera nas pessoas uma atitude defensiva que reforça o individualismo. No fundamental, a questão do desemprego é enfrentada como uma questão de desqualificação do indivíduo, e não como uma questão histórica gerada pela crise do capital. O desemprego deixa de ser problema social para se converter na 'empregabilidade' de cada um. E, alimentando-se e ao mesmo tempo reforçando esta postura, os sindicatos e partidos políticos negociam as demissões de milhares de trabalhadores em troca de algumas compensações que, ilusoriamente, seriam suficientes para que os desempregados se 'empoderassem', isto é, se qualificassem para o mercado de trabalho. Mesmo sindicatos outrora combativos, como o dos metalúrgicos do $\mathrm{ABC}$, passam a promover cursos para os novos empresários (tipo 'pequenas empresas, grandes negócios'), alimentando ilusões de que haveria saídas individuais para o desemprego. Os ex-trabalhadores se converteriam em futuros burgueses.

Que a quase totalidade dos desempregados não seguiu a trajetória fulgurante cultivada pelas ilusões deste individualismo e do nosso sindicalismo oficial é um fato sobejamente conhecido. Tendo em vista o tema deste artigo, esta opção por saídas individuais ao invés de uma luta coletiva contra o desemprego intensificou ainda mais a pressão das desumanidades sobre os processos de individuação. Se antes, no Estado de Bem-Estar, a concorrência oferecia possibilidades de 'vitórias', hoje a situação é qualitativamente distinta. As 'derrotas' não são apenas permanentes, como também são muito mais freqüentes que as 'vitórias'. O 'círculo pecaminoso' da maior produção associada ao desemprego crescente torna ainda mais evidente a desumanidade da situação de guardiões de mercadorias. A cisão entre o que somos socialmente (a porção burguesa) e o que somos intimamente (a porção cidadã) torna-se qualitativamente mais dura, mais difícil de ser afetivamente suportada, e as personalidades, de modo análogo ao que ocorre com a sociedade, começam a entrar em colapso. A depressão torna-se uma epidemia e seus efeitos econômicos são tamanhos que podem até ser mensurados. A instabilidade afetiva induz os indivíduos a uma vida frenética, tal como a instabilidade no emprego conduz as pessoas a um ritmo insano na produção. O consumo dos que ainda têm poder aquisitivo explode e talvez a moda seja o setor econômico que melhor se apoderou desta nova configu- 
ração das personalidades na era de crise estrutural do capital (Wilson, 1997; Ross, 1999). Angústia, tristeza, solidão, desespero e depressão compõem as emoções mais marcantes das vidas das pessoas em nossos dias.

Se, sempre, ser guardião de mercadoria é essencialmente desumano, com a crise das últimas décadas esta desumanidade tornou-se ainda mais intensa, dura e difícil de ser suportada.

\section{Mas não é que há saída?}

É por isso que, diferente dos antigos irlandeses, nossa alegria coletiva terminou e não tem data para retornar. Mesmo para comemorar coletivamente não podemos nos encontrar sem a mediação da violência e da raiva contra o nosso concorrente que destrói as possibilidades da nossa prosperidade de guardiões das mercadorias. A alegria de compartilhar um destino favorável não pode mais estar presente, pois não apenas nosso destino é cruel, como ainda não podemos compartilhar com nosso concorrente senão a miséria da desumanidade que nos é comum. É cada vez mais raro termos algo para comemorar com os outros - e nunca comemoramos algo com toda a humanidade. 'Terminou a alegria coletiva'. No ano que vem, ao invés da festa, teremos mais da já insuportável desumanidade. Sobrevivemos enquanto guardiões de mercadorias apenas e tão somente se tivermos a sorte de mantermos nossos empregos ou nossas propriedades e, assim, gozarmos a oportunidade de nos iludirmos de que somos melhor mercadoria do que nosso concorrente que caiu em desgraça. Mais solidão, mais angústia e menos alegrias em um cotidiano cada vez mais de guerra civil.

Hoje, esta é a relação mais profunda entre trabalho e individuação. Presos na jaula de ferro da mercadoria, os humanos estão destruindo a si próprios. As pressões objetivas se convertem nos processos de individuação em insuportáveis pressões afetivas. E também como expressão deste processo desumano, só é possível um alívio (mas como é o único possível, é supervalorizado) através de ilusões e fantasias. Por isso, enquanto esta situação perdurar, teorias e teses otimistas e fantasiosas acerca do nosso presente e do nosso futuro não deixarão de surgir a todo instante. Carecemos de ilusões, por isso elas serão produzidas.

É provável, contudo, que mais cedo do que esperamos este círculo desumano seja rompido em sua base material. Os recursos naturais e os 'recursos humanos' são finitos e não poderão ser destruídos indefinidamente. Se isto ocorrer, pode ser que as ilusões percam a sua força ideológica e os humanos possam então se libertar do feitiço que os domina. Até lá, todavia, feito zumbis em uma noite tempestuosa, o trabalho convertido em mercadoria continuará a fazer das pessoas humanas insanas 'guardiões de mercadorias'. 
Esta é a tragédia dos nossos dias.

E antes que me esqueça, a festa irlandesa é pura invenção: não encontrei outro modo de iniciar este ensaio.

\section{Notas}

${ }^{1}$ Professor do Departamento de Filosofia da Universidade Federal de Alagoas e membro da editoria da revista Crítica Marxista. Doutor em Ciências Sociais pela Universidade Estadual de Campinas. <srglessa@yahoo.com.br>

2 Feast é uma curiosa palavra inglesa. Não é festa (party) nem alegria (joy, happiness). Também não é banquete (supper, dinner). É uma festividade na qual se come muito além do ponto em que já se está farto.

${ }^{3}$ Tratamos das teses de Negri, Hardt e Lazzarato acerca do trabalho imaterial em Para além de Marx? (Lessa, 2005).

${ }^{4}$ Gabriel Kolko tem um livro impressionante sobre os efeitos da guerra na sociedade do século XX (Kolko, 1994); Mészáros, em Para além do capital (2002), faz a melhor e mais atual investigação da relação contemporânea do capitalismo com a guerra.

\section{Referências}

ENZENSBERGER, Hans M. 1995. Guerra civil. São Paulo: Companhia das Letras.

GOUNET, Thomas. 1999. Fordismo e toyotismo na civilização do automóvel. São Paulo: Boitempo.

KOLKO, Gabriel. 1994. Century of war. Nova York: The New Press.

LESSA, Sérgio. 2005. Para além de Marx? Crítica às teses do trabalho imaterial. São Paulo: Xamã.

LIPOVETSKY, G. 1997. O império do efêmero: a moda e seus destinos nas sociedades modernas. São Paulo: Companhia das Letras.

LOJKINE, Jean. 1995. A revolução informacional. São Paulo: Cortez.
MALLET, Serge. 1963. La nouvelle classe ouvrière. Paris: Éditions du Seuil.

MÉSZÁROS, István. 2002. Para além do capital. São Paulo: Boitempo.

MILLETT, Kate. 1994. Politics of cruelty. Nova York: Norton.

PIORE, Michael J.; SABEL, Charles F. 1984. The second industrial divide. Nova York: Basic Books.

ROSS, Andrew (ed.). 1999. No sweat. Londres: Verso.

SCHAFF, Adam. 1990. A sociedade informática. São Paulo: Unesp.

WILSON, Elizabeth. 1987. Adorned in dreams. Grã-Bretanha: Virago Books.

Recebido em 20/03/2006

Aprovado em 18/08/2006 